Tarih Kültür ve Sanat Araştırmaları Dergisi

Revue des Recherches en Histoire Culture et Art

مجلة البحوث التاريخية و الثقافية والفنية
Vol. 6, No. 6, December 2017

Copyright (C) Karabuk University

http://kutaksam.karabuk.edu.tr

\title{
DOI: 10.7596/taksad.v6i6.1340
}

Citation: Lazarev, A. V. (2017). Anglicisms in French Vocabulary in the Early 21st Century. Journal of History Culture and Art Research, 6(6), 187-193. doi:http://dx.doi.org/10.7596/taksad.v6i6.1340

\section{Anglicisms in French Vocabulary in the Early 21st Century}

\section{Artiom Valeryevitch Lazarev ${ }^{1}$}

\begin{abstract}
The article examines the history and causes of the widespread use of Anglicisms in French. It also presents the views of French linguists concerning the mass penetration of English borrowings into the vocabulary of the French language. Examples are given of English borrowings from different parts of speech, of the ways of their penetration and the scope of functioning in modern French. The article also provides classification of Anglicisms, as well as some examples of their replacement by French words. Various forms of assimilation of Anglicisms in French, the phenomena of the parallel use of English borrowings and their French equivalents are considered. Examples are given of semantic, semantic-stylistic, and stylistic synonymy of French words and English borrowings. The author makes examples of regulatory documents aimed at slowing penetration of foreign vocabulary into French, of the facts of public response to the use of English borrowings in French. He concludes that the number of English borrowings will inevitably grow and that this vocabulary is necessary in modern French.
\end{abstract}

Keywords: Linguistics, French, English, Borrowing, Synonymy.

\footnotetext{
${ }^{1}$ Kazan Federal University. E-mail: artiom.lazarev.fr@gmail.com
} 


\section{Introduction}

In the 17-18th centuries, in the Age of Enlightenment and scientific discoveries, along with the active word formation process, French borrowed words from English. However, until the early 20th century, their number remains insignificant. Many of them integrated into the French language and are not perceived by native speakers as borrowings. This can be exemplified by the word redingote, which is the result of the deformation of the English word riding coat (Maillet, 2014: 66).

The promotion of American culture in Europe in the early 20th century, technological progress, the economic upsurge of the United States, its military presence in France after the Second World War (Fouché, 2017) lead to introduction to the French language of a significant number of Americanisms: tank, buldozer, scooter, jeep, primetime, hit-parad, flash, etc. (Pruvost, 2012: 19). Despite the measures taken by the government to protect the French language (the Bas-Lauriol law, the Toubon law), the activities of Académie Française (French Academy) and Conseil Supérieur de L'audiovisuel (CSA) (the Superior Council of the Audiovisual) (2017) which offers French equivalents to English borrowings, articles in the French press on Anglicisms that need to be excluded from professional communication, (Baptiste, 2017) the RFI contest called Speakons français, at the beginning of the 21st century we observe the increasing process of penetration of Anglicisms into the French language. The so-called franglais (Machoul-Yatim, 2010) has got widespread use in modern French. We can speak about some "ideology and influence not only on language, but on culture as well" (Gardette, 2017). The influence of North American culture is realized through the numerous associations and organizations existing in France: L'Eglise Américaine, La Cathédrale américaine, La Bibliothèque américaine, L'hôpital américain in Paris (Bochmann, 2013). According to the US Consulate in France (2017), there are about 100,000 Americans living in France. By 2014, the number of British people living in France reached 150,000. In some communes of Aquitaine where the exodus of indigenous people is noted, their number is up to $15 \%$ of the population (Tchiveindhais, 2017).

The mass penetration of English vocabulary, "californisms" in particular (Rey, 2016), into French causes concern of lexicographer Alain Rey. Linguist Claude Hagège sees no threat, pointing out that in communication, French equivalents of English borrowings should be given preference (Toussaint, 2013). According to Jean Pruvost, a professor at Cergy-Pontoise University, the French language "protects itself": some of borrowings come out of use, giving way to French equivalents. Such nouns as teen-ager, walkman, self-service, have gone out of fashion, replaced by: adolescent (ado), baladeur, libre-service (Pruvost, 2012: 20). Examples of replacement of an Anglicisms with its French equivalents is the use of courriel instead of e-mail, texto instead of message or SMS, logiciel instead of software. However, such cases are isolated.

The objective of this study is to classify English borrowings, define the ways of their penetration into modern French, their scope of functioning, features of assimilation and the role of English borrowings in the French language, as well as an analysis of the reasons for parallel use of English borrowings and native French words.

\section{Methods}

The descriptive method is used in the study to classify Anglicisms, the ways of their penetration, scope of functioning in modern French. The comparative method is used to analyze the reasons for penetration of English words into modern French, the phenomena of assimilation and linguistic parallelism. 


\section{Results}

Anglicisms penetrate into all French parts of speech: nouns including various suffixes and derived from phrasal verbs (deal, look, must, has-been, casting, hacker, fitness, burn-out, stand-up, startup); compound nouns that have English and French word elements (voix-off (voice off), sur-booké (over-booked), drive fermier); adverbs and prepositions (after, before); interjections: Yeah!, Wow!; adjectives: OK, soft, hard, cool; adverbs live, verbs booster, flasher; acronyms: CD, DVD, USB, SMS, LOL; Htd (HowtoDie?), which is synonymous with MDR; FB (Facebook), FBO (Facebook official), meaning est le fait de passer en statut en couple avec quelqu'un sur Facebook (is the fact of becoming a couple with someone on Facebook) (Dico2rue, 2017).

Anglicisms in French can be divided into four groups:

- Words describing realia that do not exist in Francophone countries (cow-boy, bump-stock):

- Borrowings that are indispensable in everyday or professional communication (tablette, parking, gif, agenda).

- Anglicisms that can be replaced by French equivalents, but their use is attributed to the speaker's desire to emphasize the stylistic or semantic difference of a borrowing from its French equivalent: vintage, patchwork du paysage (patchwork of the landscape), melting-pot;

- Borrowings, the use of which is unreasonable: voiture (car) low-cost (French: voiture bonne marché), box Wi-Fi (French: boitier Wi-Fi), feedback (French: commentaires).

The key ways of penetration and popularization of Anglicisms in French include television, mass media, and the Internet. Thus, Anglicisms come into French from:

- Modern technology and social networks language: poster, captcha, gif, spam, troll, netflixisation;

- Show business, beauty industry: magazine people, news, fake news, fashionista, look; advertisement: Google-le, Made for sharing, we are analogue;

- Modern pop culture: télé-réalité, casting, star, street art, tag, fashion week, buzz;

- Names of cultural events: ONLYLIGHT, Against The Wind, Le Fesival OFF d'Avignon. It is not infrequent that a syntactic structure characteristic of English is used with French vocabulary preserved: PARIS DRONE FESTIVAL 2017;

- Social sphere: squatter, street pooling, sénior, manspreading;

- Gastronomy and foodservice: cake, snacking, fast-food;

- Business and professional relations: made in France, layout, helpdesk, checker, overbooker, burnout, feedback;

- Everyday communication: OK, t'es trop speed (you are too fast), t'es off (you are off), je suis en bad (I am in trouble ), il n'est pas clean (it's not clean).

English borrowing are assimilated in French. In this way, the first group verbs are formed from proper names denoting names of enterprises or commercial brands: Facebook - facebooker, Skype- skyper, Twitter - twitter; from common nouns and verbs: selfi - selfier, hashtag - hashtaguer, blog - bloguer, to like - liker, to spoil - spoiler, to boost - booster. Google's advertising slogan "Google-le" caused the verb googler to appear in the language and then its more popular form googliser. In the process of assimilation, two forms may be used in parallel: selfier - selfiser. 
In formation of French verbs describing global processes and phenomena occurring in the society, the suffix -is is used: googliser, ubériser (Lopatnikova, 2006: 263). The suffix -ation is used to derive abstract nouns from these verbs: googlisation, ubérisation, selfisation. According to our observations, uncountable nouns appear in French google, internet: c'est du google (this is a Google translation), il y a de l'internet (there is some internet).

While adapting to French phonetic system, Anglicisms retain the spelling and pronunciation that are unusual for French-speaking people spelling and pronunciation (Lopatnikova, 2006: 152-153): burpees, patchwork. The combination of $-g l,-z l$ at the end of a word is uncharacteristic of the French language. Thus, when pronouncing google, French people add [ə] between [l] and [g] and pronounce it as [gugəl], the noun puzzle is pronounced as [poezəl]. In the process of assimilation, two ways of pronunciation may be preserved. The combination of letters $c h$ in challenge may be pronounced either according to French $\left[\int\right]$ or English [t $\left.\mathrm{f}\right]$ phonetic rules.

English borrowings assimilation includes the change in the spelling of words with morpheme -man. In modern French, there are two variants of the plural, but preference is given to the variant with the ending -s: barmen-barmans, caméramen-caméramans. According to new spelling rules, in plural, the "e» is no more used in endings of English borrowings ending in -ch in singular: matchs (former spelling matches), sandwichs (former spelling sandwiches) (Dupriez, 2016: 49).

In borrowing, the French language does not borrow all meanings of a word, but one or some of them (Lopatnikova, 2006: 156). In course of assimilation of English borrowings in French, the meaning of words can be extended, narrowed, or acquire a new meaning.

The verb to zap was borrowed from English and meant to change channels on a television by using a remote control (Longman, 2017). In the process of assimilation, the meaning of the verb extended. At the moment, while preserving its primary meaning in the language, in colloquial speech it is more often used in the meaning of oublier (to forget, get out of one's head): J'ai complétement zappé mon rendez-vous! (I have completely forgotten about my meeting!), The neutral English verb acquires a new abstract meaning and stylistic coloring in French.

An example of meaning narrowing is the verb spoiler, which in French has the meaning to spoil the pleasure of watching a film by revealing its content or interesting moments (Académie Française, 2014). While in English the verb to spoil is used in several meanings: to damage (of inanimate objects), to indulge (of a person) etc. (Macmillan Dictionary, 2017).

Anglicisms also take part in forming set expressions in French, e.g., with the verb faire (do or make): faire un break, faire un burn out, se faire un challenge, faire son coming out, faire buzz, faire du forcing.

\section{Discussion}

The root causes for penetration of a large number of Anglicisms into French cannot be explained solely by the "language laziness" of native speakers, as Jean Maillet states (quoted in LeParisien, 2016), or by the fact that they sound more modern, fashionable and stylish, as put by a CSA member Patrice Gélinet (2016), since there are examples of parallel use of Anglicisms and their French equivalents: mot-dièse, balise, mot-clic instead of hashtag; toupie anti-stress instead of hand-spinner, jeune pousse instead of startup.

Anglicisms are used to describe global socio-economic political phenomena occurring in modern society (startup, ubérisation, Brexit), as well as innovations in communication and information sharing, participating in active lexical derivation (Franceculture, 2016): Uber - ubériser - ubérisation; Facebook facebooker-facebookeur(-euse)-facebookien. 
English borrowings are monosyllabic or disyllabic. They are more concise in communicating information. Thus, on French Academy web site in an article on Anglicism scoop, publier une information en exclusivité is proposed instead of the expression publier un scoop (Académie Française, 2015).

Anglicisms are used in French as euphemisms. The word black and its variant keubla refer to black people and supersedes French noir and its variant renoi.

One can note the use of Anglicisms as semantic synonyms of their French equivalents. In mass media, English adverb en live (en direct live) is used instead of en direct. According to French Academy, it is correct to use une émission en direct, retransmettre en direct (Académie Française, 2015). However, these expressions differ in the shades of meaning. Unlike en direct that means on the air, the process of transferring and receiving information at the moment with the role of the viewer ignored, - en live emphasizes the presence of the viewer en étant présent au moment des faits, en vrai (being present at the moment of the action, in truth) (Reverso Dictionnaire, 2017). The list of contextual synonyms offered on the website of L'Office québécois de la langue française (Quebec Board of the French Language) en concert, en public confirms that the Anglicisms live and the adverbial expression en live have a connotation that is absent in the French expression en direct (Banque de dépannage linguistique, 2017).

With respect to Anglicisms and their French equivalents, we are also dealing with stylistic and semanticstylistic synonymy. The synonym for fake new used in journalistic style, is a neutral word mensonge, in colloquial speech - bobard, boniment, in in common parlance - bidon. The stylistic synonym of a French verb se détendre is a colloquial verb chiller (to chill); flasher sur qqn (to flash back) means tomber amoureux de qqn (fall in love with someone). The expression c'est top! has a pronounced emotional color and is used in colloquial speech in the meaning of c'est très bien!, c'est formidable! (It's very good!, It's wonderful!)

According to our observations, in the language of the French youth, stylistically and emotionally colored superlative adjective forms coolissime, topissime appear with the suffix -issime: c'est topissime!, un playlist coolissime!

The adverb trop in colloquial speech replaces the adverb très: Elle est trop mignonne. (She is very cute). There is a lexical lacuna which is filled with an Anglicism too much: c'est too much instead of c'est trop (Académie Française, 2017).

\section{Summary}

Assimilated in French, Anglicisms retain their foreign sound and are connected by native French speakers with the latest trends in culture, with new socio-economic phenomena, and scientific achievements. In certain contexts, they can not be replaced by French equivalents, more accurately and briefly conveying the meaning that a speaker puts into his statement, giving accent to its emphatic and stylistic originality.

\section{Conclusions}

Currently, the mass penetration of Anglicisms into French seems inevitable. Their presence in modern French is necessary and raises the issue of linguistic discrimination and the aesthetic role of language in human communication.

\section{Acknowledgements}

The work is performed according to the Russian Government Program of Competitive Growth of Kazan Federal University. 


\section{References}

Académie Française (2014). Spoiler. URL: http://www.academie-francaise.fr/spoiler

Académie Française (2015). En live. URL: http://www.academie-francaise.fr/en-live

Académie Française (2015). Scoop. URL: http://academie-francaise.fr/scoop

Académie Française (2017). Too much. URL: http://www.academie-francaise.fr/too-much

Banque de dépannage linguistique (2017). Les anglicismes. Office québéquois de la langue française. URL: http://bdl.oqlf.gouv.qc.ca/bdl/gabarit_bdl.asp?id=2481

Baptiste, J. J. (2017). Vingt anglicismes à banir de toute urgence. Le Figaro. URL: http://www.lefigaro.fr/langue-francaise/expressions-francaises/2017/08/14/37003-

20170814ARTFIG00003-vingt-anglicismes-a-bannir-de-toute-urgence.php

Bochmann, K. (2013). L'anglais en France. Histoire sociale des langues de France. Rennes: Presses universitaire de Rennes.

Conseil Supérieur de l'audiovisuel (2017). Le respect de la langue française: Anglicismes: les équivalents français recommandés. URL: http://www.csa.fr/en/Television/Le-suivi-des-programmes/Le-respect-de-lalangue-francaise/Anglicismes-les-equivalents-francais-recommandes

Dico2rue (2017). Facebook Official. URL: http://www.dico2rue.com/dictionnaire.php?q=FBO

Dupriez, D. (2016). La nouvelle orthographe expliquée à tous! Paris: Albin Michel.

Fouché, N. (2017). Les américains en France (18-21 siècles). URL: http://www.histoireimmigration.fr/dossiers-thematiques/caracteristiques-migratoires-selon-les-pays-d-origine/lesamericains-en-france

Franceculture (2016). Uber, Google, Netflix...à l'assaut de la langue française. URL: https://www.franceculture.fr/sciences-du-langage/uber-google-netflix-l-assaut-de-la-langue-francaise

Gardette, H. (2017). Jusqu'où imposer la langue de Molière. Franceculture. URL: https://www.franceculture.fr/emissions/du-grain-moudre/jusquou-imposer-la-langue-de-moliere

Gélinet, P. (2016). Les anglicismes dans les médias: c'est parfois ridicule! Franceinfo. Youtube. URL: https://www.youtube.com/watch?v=APXKLiXZOfo

LeParisien (2016). Vocabulaire: on parle tous franglish. Le Parisien. URL: http://www.leparisien.fr/espacepremium/actu/on-parle-tous-franglish-16-03-2016-5630343.php

Longman (2017). Zap. URL: http://www.Idoceonline.com/dictionary/zap

Lopatnikova, N. N. (2006). Lexicologie du français moderne. - 5-е изд., испр. и доп. Моscow: Высшая школа.

Machoul-Yatim, A. (2010). Trop d'anglicismes sont entrés dans la vie courante des Français. France 24. URL: http://www.france24.com/fr/20100331-trop-danglicismes-sont-entres-vie-courante-francais

Macmillan Dictionary (2017). Spoil. URL: http://www.macmillandictionary.com/dictionary/british/spoil

Maillet, J. (2014). Langue française: arrêtez le massacre! Paris: Les éditions de l’Opportun. 
Pruvost, J. (2012). La langue française: une longue histoire riche d'emprunts. Université de CergyPontoise.

Reverso Dictionnaire (2017). En live. URL: http://dictionnaire.reverso.net/francais-definition/en\%20live

Rey, A. (2016). Culturebox Interview. La langue française est menacée par le californisme. URL: http://culturebox.francetvinfo.fr/livres/essais-documents/interview-alain-rey-la-langue-francaise-estmenacee-par-le-californisme-247537

Tchiveindhais, C. (2017). Un quart des Britanniques vivant en France sont néo-aquitains Christian. Insee. URL: https://www.insee.fr/fr/statistiques/3125028\#titre-bloc-6

Toussaint, B. (2013). La langue française va-t-elle disparaître? URL: https://www.youtube.com/watch?v=tokowdRi5BM

U.S. Embassy \& Consulates in France (2017). Policy \& History. URL: https://fr.usembassy.gov/ourrelationship/policy-history/ 